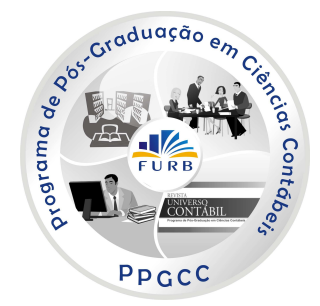

\title{
MANAGEMENT CONTROL SYSTEMS' LITERATURE DEVELOPMENT: THEORETICAL APPROACHES AND CRITIQUES WITHIN THE FUNCTIONALIST PARADIGM '
}

\section{DESENVOLVIMENTO DE LITERATURA DE SISTEMAS DE CONTROLE DE GESTÃO: ABORDAGENS TEÓRICAS E CRÍTICAS DENTRO DO PARADIGMA FUNCIONALISTA}

\author{
Marcela Porporato \\ Ph.D. in Management with specialization in Accounting and Control from \\ IESE Business School, Universidad de Navarra, Spain \\ Associate Professor of Accounting in School of Administrative Studies \\ Atkinson Building, Room 282 - York University \\ Adress: 4700 Keele Street \\ Toronto - Ontario M3J 1P3 - Canada \\ E-mail: porpomar@yorku.ca \\ Phone: +14167362100 ext 22874
}

\begin{abstract}
This paper draws a simplified map of the evolution and current state of the theories and frameworks behind management accounting within the functionalist paradigm (PUXTY, 1993) as an aid for researchers and advanced business students. The study summarily presents the paradigms recognized in management accounting as a way to provide a better perspective of the field to novice researchers. Within the functionalist paradigm the evolution of management accounting literature is documented. The historical analysis, framed as a timeline, organizes the diverse research that has dominated the field since the beginning of 1900s in clusters around a certain theory or framework. The ten frameworks identified are: 1) conventional wisdom; 2) mathematical modeling; 3) systems; 4) Anthony's framework; 5) behavioral; 6) human information processing; 7) transaction costs; 8) agency theory; 9) contingency theory; and 10) strategic. The transition from one cluster of theory or framework to another is explained by critiques; however, some theories and frameworks evolved naturally into others without the need of a critique.
\end{abstract}

Keywords: Management control systems. Literature review. Theories. Critiques. Paradigms.

\footnotetext{
${ }^{1}$ Artigo recebido em 03.10.2010. Revisado por pares em 28.12.2010. Reformulado em 18.02.2011. Recomendado para publicação em 23.02.2011 por Ilse Maria Beuren (Editora). Publicado em 30.06.2011. Organização responsável pelo periódico: FURB.
} 


\section{RESUMO}

Este artigo traça um mapa simplificado da evolução e estado atual das teorias e estruturas por trás da contabilidade gerencial dentro do paradigma funcionalista (PUXTY, 1993) como um auxílio para pesquisadores e estudantes com estudos avançados em gestão. O estudo apresenta sumariamente os paradigmas reconhecidos na contabilidade gerencial como forma de proporcionar uma melhor perspectiva do campo para pesquisadores iniciantes. Dentro do paradigma funcionalista a evolução da literatura de contabilidade gerencial é documentada. A análise histórica, estruturada em uma linha de tempo, organiza as diversas pesquisas que tem dominado o campo desde 1900 em aglomerados, em torno de uma determinada teoria ou estrutura. As dez estruturas identificadas são: 1) sabedoria convencional, 2) modelagem matemática; 3) sistemas; 4) estrutura de Anthony; 5) comportamental; 6) processamento de informação humana; 7) custos de transação; 8) teoria da agência; 9) teoria da contingência; e 10) estratégica. A transição de um conjunto de teorias ou estruturas para outra é explicada por críticas, no entanto, algumas teorias e estruturas evoluiram naturalmente para outras sem a necessidade de uma crítica.

Palavras-chave: Sistemas de controle gerencial. Revisão de literatura. Teorias. Críticas. Paradigmas.

\section{INTRODUCTION}

This paper reviews managerial accounting literature focused on the evolution of the concept of management control systems (MCS) within the functionalist paradigm. The motivation of this paper is to organize the existing literature in such a way to draw a map of the evolution and current state of the theories behind MCS, this map is based mainly on the books of Kaplan (1982), Puxty (1993), Macintosh (1994), Demski (1994), Zimmerman (1997) and Chapman, Hopwood and Shields (2007).

The purpose of this paper is to provide an overview of the disparate bodies of research literature regarding MCS in complex organizations. It covers all possible trends identified in the field of managerial accounting, in special those coming from social sciences but without entering into details of other paradigms. This is done in the absence of the straitjacket typical of US doctoral programs, which restrict research to conventional topics and methodology to neoclassical economics (PORPORATO; SANDIN; SHAW, 2003). MCS are the central nervous system of our society, while accounting its language, therefore their study shall be done from the broadest possible perspective but with a clear scope. This literature review place MCS in a large environment, complete with uncertainty, strategic considerations, and with a fuzzy demarcation between the organization and its environment.

Although the contributions to MCS evolution and understanding have been impressive, there are some contradictions that still remain. The main contradiction found so far is that from time to time the academic development of theories does not respond to the demands of practice. However the evolution observed in MCS is not random, due to the fact that the environment drives it. It is constantly observed that the major breakthroughs in the ield come from two very different sources: companies' practices and the incorporation of concepts, models and theories brought from other disciplines.

In the following pages it will be seen the evolution of MCS. The second section briefly introduces the foundations of management accounting and the rational to organize its literature in a time line. Section three summarily describes the five paradigms identified in management accounting using Puxty (1993) framework. The purpose of this section is to clearly define the scope of the study pointing out that the literature review is about the 
functionalist paradigm, the most prolific in terms of studies and researchers. The fourth section offers the main body of this paper that identifies underlying frameworks in the functionalist paradigm that could unify the body of research around some groups that share enough elements that permits to discriminate among them, arranging MCS studies in ten different frameworks.

Each of those lines of thought arises in many cases due to incompleteness of the predecessors, fact that has been reflected in the critics. Two inconsistencies, namely managerial accounting based on external reporting systems and the gap between theory and practice, are the origins of the critiques found in the literature (COATES; SMITH; STACEY, 1983; GREGORY; PIPER, 1983; SCAPENS, 1985; MACINTOSH, 1994). Section five presents the critiques that produced the major changes in predominant theories and framework within the functionalist paradigm. Finally section six merges the analysis of sections four and five into a map of how the theories and frameworks evolved and the influences the critiques had on them. The conclusion closing this study reiterates the fact that this paper dealt with MCS literature evolution within one paradigm through an analysis of ten approaches a set of critiques.

\section{FOUNDATIONS OF MANAGEMENT CONTROL SYSTEMS LITERATURE}

Economic framework played a central role in structuring MCS decision models. Other subject areas, such as management science, organization theory and lately behavioral sciences were undoubtedly present, but economics and specially the marginalist principles of neoclassical economics, had the dominant influence. MCS recognize foundations in other disciplines, such as:

a) organizational theory - the strongest influences are the organizational chart, the line and staff relationships, and the role of the controller in the organization. Management accounting followed organizational theory evolution through classical, neoclassical (behavior or human relations), systems, and contingency approaches;

b) behavioral approaches - the influence is shown in the study of behavior, motivation, habits and culture, among others. Management accounting explicit aim is to positively affect the behavior of individuals;

c) economic theory - the economic theory of cost deals with the relationship between input and output. In management accounting the curvature of the cost curve will depend on the nature of the underlying production function, being the costs a sacrifice resulting from the use of assets.

The evolution of MCS can be also assessed on historical grounds. Before the Second World War the primary focus of internal accounting was the determination of costs, with particular emphasis on product costing and the control of direct labor, direct materials and overheads. Cost accountants main mission might have been depicted as the pursuit of the absolute truth, where truth was defined in terms of getting as accurate or precise costs as possible. After the Second World War there was an increasing awareness of the view that cost information should be appropriate to the needs of users, especially managers.

In management accounting the theme of different costs for different purposes was stressed, arising a preoccupation with finding conditional truth (HORNGREN, 1975; DEMSKI; FELTHAM, 1976; KAPLAN, 1982; SCAPENS, 1985; EZZAMEL; HART, 1987). In the 1970s there was a new emphasis in the field that recognizes information costs and uncertainty, it was called the information-economics approach (KAPLAN, 1982; EZZAMEL; HART, 1987).

Some authors assert that in the 1980s seems to be a change in emphasis marked by a tend from a normative to a more positive approach (KAPLAN, 1982; EZZAMEL; HART, 
1987). As a last step in the evolution it is the appearance of radical critical perspectives, although it neither has impacted on practice nor it is well accepted in the academic arena.

\section{PARADIGMS IN MANAGEMENT CONTROL SYSTEMS' LITERATURE}

To understand the research literature in management accounting, it is necessary to understand the assumptions and reasoning behind the various frameworks that have driven management accounting research over the past decades. These perspectives or frameworks of thought and schemes for understanding and explaining certain aspects of reality is what Puxty (1993) calls 'paradigms', although they might not perfectly match the traditional definition of Kuhn (1970), they have been identified within a logical and quite coherent framework. Based on the proliferation of papers, journals and conferences, it is necessary to pay attention to paradigms in order to start organizing the map of the field. But paradigms are very tricky and might lead to wrong conclusions, such as the one of Ferrara (1995), where he wrongly identifies three so called paradigms, when in fact he is differentiating three phases of widespread use of tools and techniques. The following paragraphs briefly explain each of the paradigms identified by Puxty (1993) (see Figure 1 for a graphical representation).

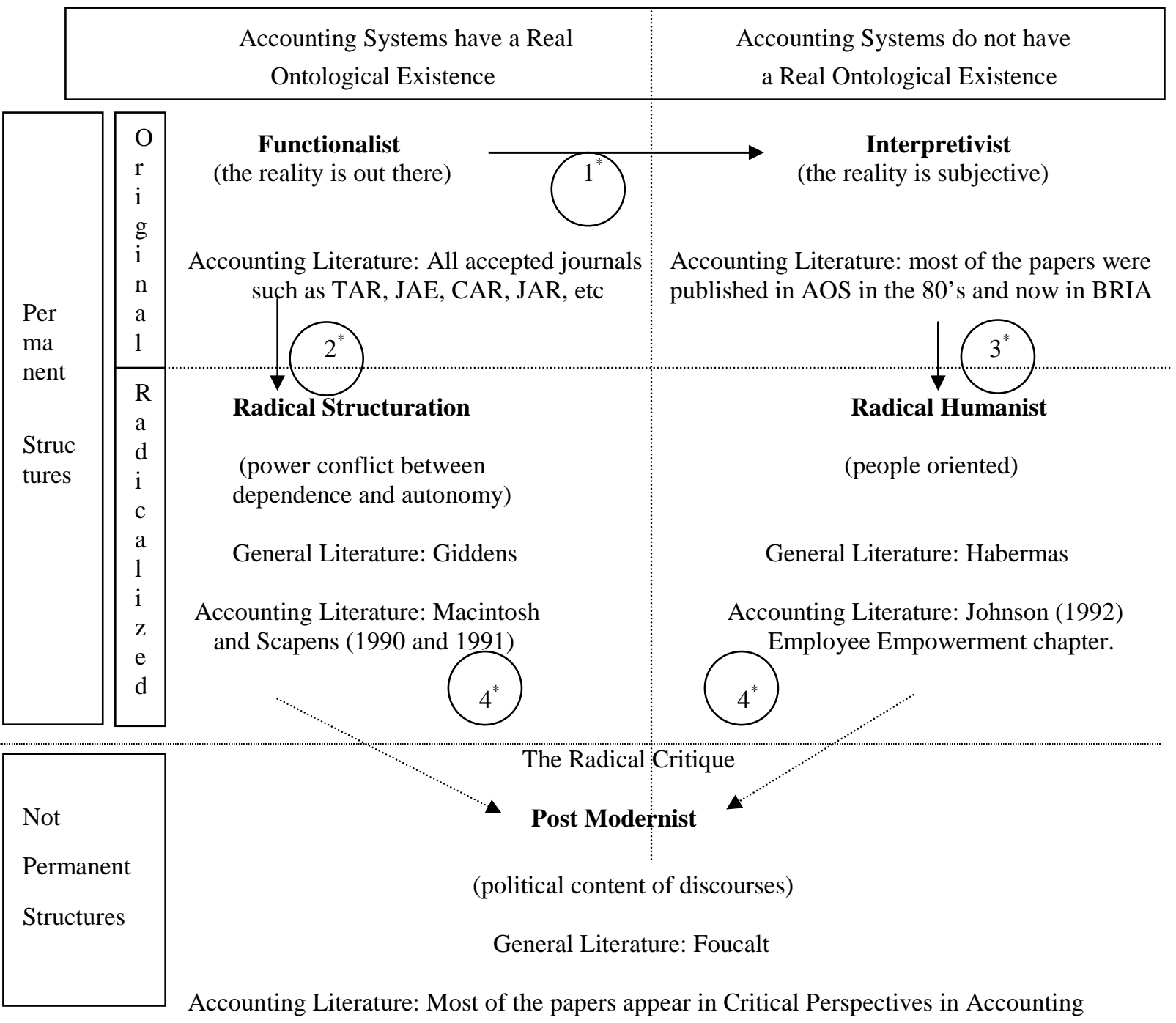

Figure 1 - Paradigms and derived models in managerial accounting

Obs.: the numbers in circles indicate the order of evolution in the literature. 
In the Structural Functionalist Paradigm accounting systems are viewed as concrete empirical phenomena, and the way of studying them is through scientific positivism. Organizations display remarkably consistent and stable patterns of behavior in their interaction with a constantly changing environment. Such stability is strong evidence that they posses effective control mechanisms, being one of them the organization's internal accounting system that can be objectively assessed and studied (EMMANUEL; OTLEY; MERCHANT, 1990). In this paradigm are discussed topics such as mechanistic vs. organic views, open versus close systems, commands vs. markets view, information processing, rational contingency approach and strategic planning. Most of the development of the MCS field is encompassed within this paradigm and as such this study is focused on the evolution of frameworks and theories within this paradigm.

In the Interpretivist Paradigm accounting systems are not viewed as a concrete reality out there. The subjective interpretivist paradigm seeks only to understand, therefore most of its studies are interested in the symbolic use of accounting. Authors in this paradigm say that many of the phenomena treated by positive theory are not available to the senses, and hence cannot be conceived as objective (PUXTY, 1993). Crucially they developed this thesis to argue that there is no value-free observation or value-free theorizing. Tinker, Merino and Neimark (1982) contend that accountants have been influenced by one particular viewpoint in economic thought (utility-based, marginalist economics) with the result that accounting serves to bolster particular interest groups in society. Hopwood (1987) is a good example of this line of thought. Although in the last years there have been numerous studies and researchers aligned within this paradigm, this study will not devote much attention to it besides mentioning the main theories in use (MILLER, 2007).

The Radical Structuralist Paradigm is built around the work of Giddens (1976). It is derived from the structural functionalist paradigm because it agrees in the concept of accounting systems as having a real ontological existence, but it differentiates because it seeks to explain dialectic confrontation between dependence and autonomy that arises because of the use of these systems. Good examples in accounting are Macintosh and Scapens (1990; 1991).

The Radical Humanist Paradigm derives from the interpretivist paradigm and builds around the concepts of Habermas $(1984,1987)$. It also relies in a subjective social world, but has a more strong people-oriented vision, generating the discussion regarding employee accounting systems. Accounting is not a neutral source of information that led to the sociallydesirable goal of efficiency, but is a system that reinforces the power of the owners over their employees by permitting control over every aspect of their work through the detailed analysis of costs (PUXTY, 1993). Some of its arguments can be found in the chapter of employee empowerment of Johnson (1992).

The Postmodernist Paradigm is a step further because the previous four paradigms can be considered modernists. The main characteristic identified is the rejection of permanent structures, and the political influence of discourses, as stated by Foucault (1980). The proponents of this paradigm assert that they do not longer believe that through continued model building we can reach a synthesis of knowledge with which to instruct the practitioner in the right way to design or use management accounting systems (PUXTY, 1993). Within this paradigm the radical critiques emerged. The radical critique suggests that the discipline of MCS can also be regarded as a discursive practice following Foucault (1980). As a discursive formation, it views the manager as the person with the authority to make decisions, with command over subordinates and resources within a designated responsibility center, and with responsibility for its financial performance (MACINTOSH, 1994).

The postmodernist paradigm is in its infancy, but it seeks to point out and explore the wider web of connections within which a control system is embedded. Although new, it 
already has its own journal called Critical Perspectives in Accounting, and Hopper and Macintosh (1993) is a good reference in accounting, but not the only one. In Covaleski and Dirsmith (1990) the point of view is the symbolic role of accounting in organizations and society, where accounting is conceived as one form of symbol that is used in the social construction of a fluid, subjective reality. Otley (1994) suggests that the world taken for granted in the design and operation of traditional MCS is increasingly inappropriate and such systems are likely to prove ineffective in maintaining organizational coherence. Cooper and Puxty (1996) uncover the truths through historical studies and reject the notion that there are real referents to which we can have direct access without a mediating language. A neat recent example of this paradigm is Sikka and Willmott (2010) where the authors approach transfer prices not as a technique for optimal allocation of costs and revenues among divisions, but as a mean of enhancing private gains by minimizing and avoiding the payment of public taxes.

\section{FUNCTIONALIST PARADIGM: THEORETICAL APPROACHES}

This section offers a brief summary of the main bodies of research that can be identified in MCS from a historical perspective within the functionalist paradigm. Some of these areas represent the major ongoing research efforts (CHAPMAN; HOPWOOD; SHILEDS, 2007).

\subsection{Old Conventional Wisdom}

Traditional textbooks have a list of topics that, despite the differences in orientation, are common to all. It is agreed that the final developments in MCS occurred in the early decades of the twentieth century to support the growth of multi-activity and diversified corporations such as Du Pont and General Motors (KAPLAN, 1982 and 1984; SCAPENS, 1985; BORITZ, 1988; JOHNSON; KAPLAN, 1987; ATKINSON, 1989; PUXTY, 1993). Up to here an engineering point of view was dominant with cost accounting being the first manifestation of the current MCS, other contributions of this period are the concept of differential costs, marginal costs, return on investment (ROI), and budgeting.

This stage is based on an absolute truth approach and principles of management. Giglioni and Bedeian (1974) provide a good overview of the roots of management control issues that lie in early managerial thought. Follet (1927) saw that the manager controlled not single elements but complex interrelationships and argued that the basis for control lay in selfregulating, self-directing individuals and groups who recognize common interests and objectives. Emerson (1912) may be credited with the first meaningful contribution to the development of 20th century management control theory, in 'The Twelve Principles of Efficiency' he heavily stresses the importance of control. Church (1914) also contributed to the development of early management control theory; for him one of the five organic functions of administration was control, identified as the mechanism that coordinates all of the other functions and in addition supervises their work. Fayol (1949) identified control as one of the five functions of management, being control the verification whether everything occurs in conformity with the plan adopted, the instructions issued and principles established. It is interesting to note that Lawson (1920) was the first text devoted entirely to the subject of management control, while Urwick (1928) was the first author to identify a set of five control principles: responsibility, evidence, uniformity, comparison and utility. One of the first empirical studies of corporate organization and control was performed by Holden, Fish and Smith (1941), where one of its conclusions was that control is a prime responsibility of top management.

Historical studies have played a conspicuous role in management accounting in recent years. Both research and practice have been strongly influenced by Kaplan (1984) and 
Johnson and Kaplan (1987), who based on reviews call for more relevant product costing. As a precedent Chandler $(1962 ; 1977)$ showed the importance of cost and management control information to support the growth of large transportation, production and distribution enterprises during the 1850-1925 period. Management accounting systems evolved in the late 1880s to provide information about internal transactions, and by mid 1920s they were being used for activities as diverse as planning, controlling, motivating, analyzing and evaluating (BORITZ, 1988). Johnson (1981 and 1983), Johnson and Kaplan (1987) and Lee (1987) made a convincing case for the development of managerial accounting practices in the US where real changes have not occurred is spite of changes in sheer size and scope of the enterprises from the late $19^{\text {th }}$ century until today. Despite those arguments it is interesting to note that there is no difference between the role of MCS depicted by Johnson (1981 and 1983) and that explained by De Roover (1974) regarding the Medici Family (Florence) and Fugger Family (Austria) some centuries ago (FLAMHOLTZ, D. 1983). The absence of specific evidence on how new management accounting information changed business decisions is striking. The more this history is condensed, as in Johnson and Kaplan (1987), the more it can leave us with the wrong impression that management accounting responded smoothly to environmental changes in the past, meeting the information needs of management as those needs arose (LUFT, 1997). Current works on this stream can be found in history journals such as Accounting, Business and Financial History, Business and Economic History on-line or Review of Accounting, Finance and Economics. Also old traditional and conventional concepts are the very heart of any management accounting textbook.

\subsection{Mathematical Modelling}

The 1960s and 1970s saw a massive effort to refine traditional calculation using mathematical and statistical analysis. The peak of this line of thought happened in the 1960's and 1970's. During the 1960s in a large variety of departments, operations research became to be modeled in an academic manner (PUXTY, 1993, considered it was not reality modeling at all, but the "study of the delights of algorithms"). The introduction of these quantitative techniques, however, did not extend the domain of MCS literature.

Between 1960 and 1975 a stream of articles appeared showing how operations research techniques could be applied to cost data to provide information relevant to a broad variety of management decisions and control problems. The operations research literature could therefore be viewed as the successor to the scientific management era of cost accounting (1880-1920) in which careful attention was focused on improving the local efficiency of the workplace, on developing techniques to aid lower-level managerial decisions, and on monitoring operating performance (JOHNSON; KAPLAN, 1987).

Researchers attempted to extend models for cost estimation, cost-volume-profit (CVP) analysis and cost variance to explicitly recognize uncertainty. During the 1960s and 1970s several researchers extended the simple traditional CVP model so that it could be employed in less restrictive business settings, for instance Jaedicke and Robichek (1964) is the first treatment of CVP in the context of uncertainty, Goggans (1965), Givens (1966) and Morrison and Kaczka (1969) used differential calculus for the solution of break-even points with curvilinear parameters, Ferrara et al. (1972) used simulation to develop the probability distribution, and Liao (1975) used model sampling and a curve-fitting techniques in order to obtain estimates of the profit probability distribution and its moments.

In our days it is difficult to find papers that adopt a pure mathematical modeling approach. Nevertheless, current works on this stream can be found in quantitative accounting journals such as the Journal of Accounting and Economics, Review of Quantitative Finance and Accounting and Journal of Accounting Research. Searching for current literature the more similar paper that could be found is Banker and Hughes (1994) where the authors' model 
answers whether the aggregation of cost information as in an activity based cost system provides the relevant information for pricing decisions. A set of studies identified as 'sticky costs' can be also grouped within this framework. Anderson et al. (2003) concluded that costs are sticky because in their analysis of 7,629 companies in a span of 20 years, the selling, general and administrative (SG\&A) costs increased in average $0.55 \%$ per every $1 \%$ of increase in the level of sales, and those same costs diminished in average $0.35 \%$ when the sales fall in a $1 \%$.

\subsection{Systems Approach}

Cybernetic models are dynamic models with one or more correcting feedback loops. Organizational theory in general and management control research in particular has been influenced considerably by cybernetics. The major contribution of cybernetics has been in the study of systems. The cybernetic model is very mechanistic and imposes a rationalistic framework for the analysis of organizational control (DENT; EZZAMEL, 1987). These models implicitly assume that management control is essentially the same basic process as is found in physical, biological and social systems, the only change is that human regulators are substituted for mechanical regulators, implying that cybernetic control systems do not learn (HOFSTEDE, 1981). The notions of accounting variance analyses and management-byexception which appear in every management accounting textbook are consistent with the basic cybernetic view of control.

The key to understanding the systems approach is to realize that its foundations lie in attempting to overcome reductionism, however early theorists treated organizations as closed systems. Prior to 1960 most theorists tended to assume that organizations could be understood apart from their environments (OTLEY; BROADBENT; BERRY, 1995). During the late 1950s the models started to adopt an open system approach and the applications of systems ideas to organizations flourished during the 1960s (EMMANUEL; OTLEY; MERCHANT, 1990). The systems approach studies the activities of an organization by reference to the context of the wider environment in which it is set. The system movement recognizes as founding roots the article of L.von Bertalanffy called 'The Theory of Open Systems in Physics and Biology' in 1950, and the formation of the Society for General Systems Research in 1954 (PUXTY, 1993). One works that is often quoted in MCS is Boulding (1956) who suggested that were nine levels of systems: static, clockworks, goal-oriented, open, plant, animal, human world, human organizations, and transcendental.

An accounting system cannot be viewed as a control system per se, rather it must be part of a carefully designed total system of organizational control. Flamholtz, E. (1983) shows that control mechanisms must be integrated in a more complex level of systems to be effective, for this author the systems interrelated are the core control system, organizational structure, organizational culture, and organizational environment. Accounting must be viewed more as a component of a socio-technical system rather than merely as a technological control mechanism that operates in isolation of an organization's particular values, beliefs and norms. A similar framework is offered by Flamholtz, Das and Tsui (1985), although it is cybernetic in nature, it accommodates an open systems view of the organization and its environment. According to the authors the core control system is made up of mechanisms such as planning, measurement, feedback and evaluation-reward. In our days it is difficult to find papers that adopt a pure systems approach.

\subsection{Anthony Framework}

Management control is one of the three types of planning and control activities that occur in an organization. Anthony's framework (ANTHONY, 1965) determines the existence 
of three classes of planning and control activities with minimum overlaps: strategic planning, management control and task control. In his framework the three types constitute a hierarchy because task control follows the management control rules and management control exists to achieve the strategic plans. The three differ in many ways, including the organizational level of the personnel involved, the amount of judgment required, the timing of their consequences, and the importance of a single action taken (MERCHANT; SIMONS, 1986). The management control function includes making the plans that are necessary to implement strategies, and it is the process by which managers influence other members of the organization to implement the organization's strategies (ANTHONY, 1965). Anthony and Govindarajan (2007) change the first element for strategy formulation but the general approach rests on the same basic assumptions. Goal congruence is a central topic although nowadays is analyzed with a deeper behavioral approach.

Robert Anthony recovered the old concept of different costs for different purposes. Anthony's textbooks concentrate upon planning and control through accounting rationales and contain little discussion of social-psychological or behavioral issues, despite he specifically mentions them (OTLEY; BROADBENT; BERRY, 1995). Anthony developed a demarcation of management control from strategic control and operational control that has placed management accounting as a function of the last one (PUXTY, 1993). Despite having been an important contribution to management accounting, Anthony (1965) seminal work restricted management control to an accounting-based framework which has been unnecessarily restrictive (OTLEY; BROADBENT; BERRY, 1995).

Current works on this stream can be found in two of the textbooks most widely used in Universities to teach MCS: Anthony and Govindarajan (2007) and Merchant and Van der Stede (2007). Merchant and Van der Stede (2007) suggest that control systems have two basic functions: strategic control and management control; also they organize their framework of tools around three types of controls: action, results and personnel or cultural. The first characteristic make Merchant's work somewhat similar to the division identified by Anthony, however the second characteristic makes his work more in line with contingency theory (GROOT; MERCHANT, 2000).

\subsection{Behavioral Accounting}

This line of thought emerges as an opposing perspective to those where human beings were not considered. This approach pays extensive empirical and theoretical attention to the effects of accounting systems on people, and the effects of people on accounting systems using models from psychology and social psychology. The three major contributors to behavioral science knowledge are psychology (interested in how individuals behave), sociology (social behavior), and social psychology (groups behavior) (SIEGEL; RAMANUSKAS, 1989). This approach starts to be relevant and widely accepted by mid 1970's.

The main proposition is that measurement is neither neutral nor objective. People within the system change their behavior as a function of the measure chosen to summarize the economic performance of their organizational unit (KAPLAN, 1982). Behavioral accounting studies can be organized around three issues: the effect of human behavior on the design, construction, and use of the accounting system; the effect of the accounting system on human behavior; and the methods to predict and strategies to change human behavior (SIEGEL; RAMANUSKAS, 1989). In this line of thought discussions are mainly related to attitudes (beliefs, opinions, values and habits), motivation (needs and expectancy theories), perception (selection, organization and interpretation of stimuli and individual predisposition), learning (classical and operant conditioning), and personality (SIEGEL; RAMANUSKAS, 1989; BELKAOUI, 1991). 
The accounting profession's awareness of and interest in the behavioral aspects of the discipline began to develop in the early 1950s. The interest in the behavioral consequences of control systems operation was first introduced by Argyris (1952) in his book. Other pioneering studies were Hofstede (1968) who highlight the effect that varying budget levels could have on motivation, Ronen and Livingstone (1975) that conceptualized a model utilizing the expectancy theory of motivation (BIRNBERG; TUROPOLEC; YOUNG, 1983; BUCKLEY, 1983). There was thus a growing awareness of the human consequences of control systems use and operations beginning to emerge in the early 1970s, perhaps lagging some 20 years behind the equivalent human relations movement in the organizational theory literature (OTLEY; BROADBENT; BERRY, 1995). In spite of its evolution, much of this behavioral research is fragmentary, and several major strands followed from realizing that existing management accounting practices could have dysfunctional consequences (SCAPENS, 1985).

Current works on this stream can be found in behavioral journals such as Behavioral Research in Accounting, International Journal of Behavioral Accounting and Finance. Among the most recent publications Nikias et al. (2010) can be mentioned, they conducted an experiment on the effect of aggregation and timing on budgets in a setting of information asymmetry. They found that a disaggregated, sequential budget system leads to less slack.

Behavioural accounting encompasses a broad set of studies that are better identified with the interpretivist paradigm. Current trends known as institutional theory, political economy, ethnography and networks tend to be classified as interpretivist studies where MCS are not perceived as an objective entity to study (MILLER, 2007). Studies that rely on the idea of the 'myth structure' of Meyer and Rowan (1977) are normally linked to institutional theory such as the works of Covaleski and Dirsmith (1998) and Fligstein (1990). Institutional theory has attracted a significant amount of research, however the other interpretivist frameworks have highly valuable studies (MILLER, 2007): political economy (BOUGEN et al., 1990; FROUD et al., 1998), ethnography (PRESTON et al., 1992; CHUA, 1995) and networks (ROBSON, 1991; and all other papers that mention GRANOVETTER, 1985, as the main theoretical reference).

\subsection{Human Information Process (HIP)}

Receptive to the critics made by the behaviorist, the conventional wisdom evolved to incorporate the concept of bounded rationality. Under this perspective, human beings and managers specially, cease to be perfect individuals with an infinite capacity to process information. One basic element is the substitution of the concept of maximizing by satisfying in the late 1970's and early 1980's. Rooted in behavioral decision theory, which itself relies heavily on cognitive psychology, this stream of research is based on the individual decisionmaker faced with accounting information. Early decision-making approaches studied organizational information flows and decision-making processes (BARNARD, 1938; SIMON, 1957). The determining factor of organizational functioning is suggested to be limited rationality and information-processing abilities of the human beings that make it up (EMMANUEL; OTLEY; MERCHANT, 1990). A central concept to HIP is the principle of bounded rationally, which has been identified and described by Simon (1957, p 198) as "the capability of the human mind for formulating and solving complex problems is very small compared with the size of problems whose solution is required for objectively rational behavior in the real world".

Since 1967 a growing number of HIP studies have been undertaken in the auditing field. Otley (1983) pointed out that most psychological findings regarding human information processing have been replicated in accounting contexts. Underlying HIP research is the basic model of man as an information processor. Hogarth (1980) identified four major concerns 
regarding man's limited information processing ability: perception of the information, the nature of processing, processing capacity, and memory. Complementary Eggleton (1986) suggested that individuals form abstracted prototypes of processes. Siegel and Ramanuskas (1989) presented three types of process models identified as: economic (all human actions and decisions are perfectly rational and within an organization there is consistency among the various motives and goals), social (humans are basically irrational and decisions are based primarily upon social interaction), and satisfying (Simon's concept of the administrative man, in which humans are viewed as rational because they have the capacity to think, process information, make choices, and learn). Another approaches are provided by Powell (1987) who worked with the lens model (describes the decision situation with reference to the interaction between the environment, the question the decision maker receives and the responses), probabilistic judgment (considers the decision maker's use of subjective probabilities), and cognitive style approach (states that individual differences between human beings exist, although the exact nature is unclear).

It is difficult to find papers in management accounting journals that rely on this model, however HIP is a significant component of behavioral studies, particularly those in auditing. Nevertheless, it is worth to notice that Lipe and Salterio (2000 and 2002) make an interesting use of the HIP ideas in two papers that have been significantly cited. Their studies suggest that when managers use the balanced scorecard for performance evaluation purposes, the subjects use strategies that simplify the absorption of information: use only common measures (LIPE; SALTERIO, 2000), or decide about the performance in each perspective without paying much attention to discrepant measures within each perspective, this phenomenon has been labeled as 'divide and conquer' (LIPE; SALTERIO, 2002).

\subsection{Transaction Costs}

Accountants begun looking at a theory developed by economists and organizational theorists as a possible framework to explain the development and design of managerial accounting and information economics that became popular in the 1970s. Many authors consider that agency theory is included in this line, but for the purposes of this paper, agency theory will be considered under the following heading. The economics of internal organization literature generally adopts the bounded rationality concept of economic behavior (rather than utility maximization) and the analysis is far less structured that agency theory (SCAPENS, 1985; BAIMAN, 1990). In transaction costs economics (TCE) the main assumptions are opportunistic behavior, bounded rationality, incomplete contracts and imperfect enforcement of contracts. The idea motivating transaction costs research is that transactions are organized so as to minimize transaction costs; therefore its emphasis is on the contractual relationships between firms. The main insight provided is that governance matters and incomplete contacts give rise to ex-post opportunistic behavior that distorts ex ante investments in relationship specific assets.

The information economics approach was developed from the mid 1960s onwards. Ezzamel (1987) considers that much of the pioneering work had been contributed by Marschak and Radner (1972). Accounting researchers used the Marschak and Radner (1972) work as the corner-stone in their modeling of information economics (DEMSKI 1972a, 1972b, 1980; DEMSKI; FELTHAM, 1972). Many of these researches have been concerned with using mathematical modeling to approach the problem of the selection of accounting systems on the basis of their uncertain costs and benefits. The analysis initially proceeds by assuming that information can be obtained at no cost, this assumption is subsequently relaxed and the costs of information are explicitly incorporated into the model. Some authors focus on the characteristics of markets and hierarchies and the costs of transactions in each form of economic organization. Williamson $(1970 ; 1975 ; 1981)$ developed the theory of markets and 
hierarchies in which the ramifications of internal organization are explicitly considered. In this context the organization is treated as a network of exchanges or transactions which should be regulated in the most economic manner. Markets and hierarchies is a positive theory trying to explain organizational arrangements that are most economical for mediating transactions in different settings.

In managerial accounting the main impact has been achieved by the design of generic control mechanisms. Ouchi (1979) is a classic paper that based in organizational theory and economics identifies three control mechanisms (markets, bureaucracies and clans), which use depends on several characteristics and conditions. In a market, prices convey all the information necessary for efficient decision-making (ARROW, 1974), while the bureaucratic model (WEBER, 1947) is a fundamental mechanism of control that involves close personal surveillance and direction of subordinates by superiors. Market is a far more efficient mechanism of control in terms of the administrative overhead consumed, because prices are a far more efficient means of controlling transactions than rules. However, the conditions necessary for frictionless prices can rarely be met, and in such conditions the bureaucratic form, despite its inadequacies, is preferred. A clan is the most demanding while the market is the less demanding with respect to social underpinnings, although the opposite is true when it comes to information. The ability to measure either output or behavior, which is relevant to the desired performance, is critical to the rational application of market and bureaucratic forms of control.

Current readings on this area continue to appear. Zimmerman (1997) in his book approaches the whole subject of management accounting from a transactions cost perspective because since the very beginning he asserts that management accounting cannot be properly understood without a prior theory of the nature of organizations. He sees management accounting as an organizational design problem, involving designing the optimum partitioning of decision rights, the establishment of systems for measuring and evaluating performance and the choice of a system for linking rewards / promotions to measured performance. Organizations will typically face a trade-off between designing the accounting systems for decision making purposes and designing it for control purposes. Bello, Lohtia and Dant (1999), Anderson, Glenn and Sedatole (2000) and Dekker (2004) rely on transaction costs to explain real situations, demonstrating that this approach can be used to frame sourcing decisions and model interorganizational costs.

\subsection{Agency Theory}

The irruption of economics in the field led academicians to work on very elegant mathematical models. Agency theory and transaction costs are a refinement of the mathematical modeling based on economic concepts and theories. The agency relationship exists when one or more individuals, called principals, hire others, called agents, in order to delegate responsibilities to the agents as they are specified in their mutually agreed contract. The contract, that regulates the employment relationship, contemplates the compensation agreement, information systems, allocation of duties and allocation of ownership rights (JENSEN; MECKLING, 1976). Agency theory is built around the key ideas of self interest, adverse selection, moral hazard, signaling, incentives, information asymmetry and the contract (MACINTOSH, 1994). It provided frameworks to analyze the interaction of selfinterested individuals within an economic context, to understand the determinants and causes of efficiency losses created by cooperative and self-interested behavior, and to elaborate on the implications of different control processes designed to mitigate the efficiency loss from agency problems.

During the 1970s researchers modified the economic model on which management accounting's conventional wisdom was built. They introduced uncertainty and information 
costs into management accounting models. Agency theory researches have taken this modification process a step further by adding some behavioral considerations to the economic model. Although the agency model relies on marginal economic analysis, it includes explicit recognition of the behavior of the agent whose actions the management accounting system seeks to influence or control (SCAPENS, 1985). Baiman (1990) recognizes three branches of agency theory: principal-agent, transaction costs and Rochester school based on the work of Jensen and Meckling (1976). The principal-agent model typically takes the organization of the firm as given and concentrates on the choice of ex-ante employment contracts and information systems (BAIMAN, 1990). The objective of the Rochester model was in understanding how agency problems arise and how they can be mitigated by contractual, and more generally by organizational design (BAIMAN, 1990). In spite of the existence of the three branches, the first is the prominent one.

There are many papers in agency theory, however, the classic ones are clearly identified. The agency model studied by Ross (1973) does not allow the agent to be better informed than the principal, Holmstrom (1979), extended the basic model to allow for situations in which the agent had access to private information. Holmstrom (1979) sets up a model principal-agent where effort is not observable, moral hazard exists, and information asymmetries arise in long term contracts. Only a second best solution, which trades off some of the risk-sharing benefits for provision of incentives, can be achieved. The source of this moral hazard or incentive problem is an asymmetry of information among individuals that happens because individual actions cannot be observed and hence contracted. By creating additional information systems, as cost accounting, or by using other available information about the agent's action or the state of nature, contracts can generally be improved.

Agency theory makes important contributions to management accounting, specially improving its modeling skills. Christensen (1981) makes a clear link between agency models and managerial accounting communication devices, specially budgeting; he showed that the agency is not always better off if the agent is supplied with more information, since he might use that information to shirk. Rogerson (1985) is a model that links memory (in repeated games) with preferences, because the repetition of a moral hazard relationship creates the opportunity for intertemporal risk sharing. Miller and Buckman (1987) explores and confirms the statement of Zimmerman (1979) that fixed costs allocations are appropriate surrogates for the opportunity costs of using service departments, because there is overcongestion if no cost is placed on the use of the fixed resource. Antle and Demski (1988) use agency theory to model compensation plans at a theoretical level. Banker, Datar and Kerke (1988) suggests that excess capacity is required to absorb overloads arising from uncertainties in the timing of orders and variability in set-up and processing. Foster and Gupta (1990) empirically analyze manufacturing overhead from three perspectives, finding that volume is better explanation than efficiency or complexity. Nandakumar, Datar and Akella (1993) developed a model of quality costs and optimization strategies in total quality management. Among academicians this is one of the dominant approaches today, maybe because it is perceived as being of enough quality to be accepted in traditional financial accounting journals.

\subsection{Contingency Theory}

As a way to reconcile the two opposing approaches of agency theory and behavioral accounting, and to enrich HIP, contingency approach arises and consolidates in the early 1980's. The contingent control literature is based on the premise that a correct match between contingent factors and a firm's control package will result in desired outcomes. Contingency theory explains how an appropriate accounting information system can be designed to match the organization structure, technology, strategy and environment of the firm. It suggests that universal applications are inappropriate and a framework for analysis is developed to suggest 
alternative performance measures, incentives and evaluation uses in organizations (OTLEY, 1980; EMMANUEL; OTLEY; MERCHANT, 1990).

As is the case of the other approaches, contingency theory also borrowed something from other disciplines. The contingency approach in organization theory was a reaction against scientific management and human relations approaches, both of which had prescribed universalistic rules for management (PUXTY, 1993). Galbraith (1973) outline some studies such as Burns and Stalker (1961) who differentiate mechanistic vs organic type of organizations, Woodward (1965) that showed that structure relates to effectiveness only when production was controlled for, and Lawrence and Lorsh (1967) were able to develop two basic concepts and mechanisms known as differentiation and integration. In management accounting the conflicting finds of Hopwood (1972) and Otley (1978) could be reconcile only by adopting a contingent approach, and Birnberg Turopolec and Young (1983) attempts a unified contingent framework based on the ideas of Thompson (1967), Perrow (1970) and Ouchi $(1979 ; 1980)$. It was only in the late 1970s that the open systems ideas began to be reflected in the contingency theory framework, which followed primarily from the use of environment as a contingent variable.

Several authors have made very clever organizations of the studies that rely on contingency theory. Chapman (1997) is an interesting paper that covers contingency theory in management accounting from its very beginning. He identifies three main streams: accounting performance measures (HOPWOOD, 1972; HAYES, 1977; HIRST, 1981), centralization of control and accounting (BURNS; WATERHOUSE, 1975; GORDON; MILLER, 1976; WATERHOUSE; TIESSEN, 1978), and strategy and accounting (HAMBRICK, 1981; GOVINDARAJAN; GUPTA 1985; SIMONS, 1987, 1990). Another point of view can be taken if we follow the literature review of Fisher (1995) that provides an overview and synthesis of the research literature on contingency theory and management control in complex organizations. His classification is based on the levels of contingent control analysis, that generates four levels of correlations: one contingent factor with one control system variable (MACINTOSH; DAFT, 1987; THOMPSON, 1967), contingency / control interaction on an outcome variable (GOVINDARAJAN; GUPTA, 1985; SIMONS, 1987), system approach to contingent control design (WATERHOUSE; TIESSEN, 1978; GOVINDARAJAN; FISHER, 1990), and simultaneous multiple contingent factors (FISHER; GOVINDARAJAN, 1993). The last effort to offer a clear overview of this theory is offered by Chenhall (2007).

The literature review done for this study finds that major contributions in contingency theory go back to the late 1970s. Hayes (1977) is a basic and classical paper on contingency theory. The author works with three factors that are subunit interdependence, environmental relationships and factors internal to the particular subunit of interest, and finds that they systematically differ across different functions such as R\&D, marketing and production. Ouchi (1977) is an empirical paper that separates structure from organizational control, being the control system of the organization embedded in its structure. The control system seems to consist of two parts: a set of conditions which govern the form of control to be used, and the control system itself that could be based on output or behavior controls. His conclusion is that the more non-routine and unanalyzable the task, the less appropriate behavior control is, and the more important output control ought to be. Hofstede (1981) is a good example of this approach, he uses four criteria to come up with six types of management control: routine control (prescribed in precise rules and regulations), expert control (entrust control to an expert), trial-and-error control (learn to control through its own failures), intuitive control (management control is an art rather than a science), judgmental control (control of the activity is subjective), and political control (use of hierarchy, rules and policies and negotiation to solve ambiguities). Eisenhardt (1985) integrates organizational approaches and agency theory to come up with a model of control systems design where the task 
characteristics determine which control strategy is appropriate. More programmed tasks require behavior based controls while less programmed tasks require more elaborate information systems or outcome based controls.

Studies using contingency theory frameworks can be found in a varied set of journals such as Accounting, Organizations and Society, Journal of Management Accounting Research, and Qualitative Research in Accounting and Management. Although this approach is an active theory, it had been criticized on valid grounds by various authors. Otley, (1980) asserts that its propositions are too general, vague and weak in terms of empirical tests. This approach is appealing because it can explain almost everything that does not fit completely in others, however contingency theory reviews are largely negative proclaiming the lack of an overall framework for the analysis of the relationship between contingent factors and accounting (CHAPMAN, 1997; CHAPMAN; HOPWOOD; SHIELDS, 2007).

\subsection{Strategic Accounting}

Strategic accounting is the last stream of thought that had an important impact on MCS. Two schools can be found, one related with K. Simmonds and Chandlers seeks to understand the causes and effects, and the other associated with Robert Kaplan, Thomas Johnson and Robin Cooper has taken an interest in developing new cost control and decision methods (PUXTY, 1993). The second line has the dominant presence in today's MCS literature. Tom Johnson advanced the activity management approach as a vital ingredient for companies pursuing total quality management and just-in-time operations, while Bob Kaplan with Robin Cooper, extended the transaction-costs approach into comprehensive activitybased cost management systems (JOHNSON; KAPLAN, 1987) and latter R. Norton with R. Kaplan developed the balanced scorecard (KAPLAN; NORTON, 1996) and the supportive idea of strategic maps.

The traditional view of MCS as passive and relatively unchanging reflections of corporate strategy is open to doubt. MCS may also be used interactively by top management to focus organization members' attention on the threats and opportunities presented by a changing and uncertain environment (EMMANUEL; OTLEY; MERCHANT, 1990). The strategy-control fit is expected to foster such a commitment to the current strategy, however, if the control system is too closely related to the current strategy, it could result in overcommitment, thereby inhibiting the manger from shifting to a new strategy when he/she should (ANTHONY; GOVINDARAJAN, 2007).

Most of the authors agree that understanding and analyzing the cost structure of a firm is the key to developing successful strategies. Cost analysis is traditionally viewed as the process of assessing the financial impact of managerial decision alternatives; however strategic cost analysis is cost analysis in a broader context, where the strategic elements become more conscious, explicit, and formal (SHANK; GOVINDARAJAN, 1989). Porter (1985) has developed a good tool to perform a strategic cost analysis that involves the following steps: 1) define the firm's value chain and assign costs and assets to value activities, 2) identify cost drivers regulating each value activity, and 3) examine possibilities to build sustainable competitive advantage either through controlling cost drivers or by reconfiguring the value chain. Other interesting methodology has been proposed by Kaplan and Cooper (1994). They identified three areas of action of strategic activity-based management, namely: product mix and pricing, customers and supplier relationships, and product development.

Although this is the newest development, interesting literature reviews can be found (DENT, 1990; LANGFIELD-SMITH, 1997). The first contribution was the link of strategy to performance through incentive plans and control design (GOVINDARAJAN; GUPTA, 1985; SIMONS, 1987). MCS function was enriched to control strategy plans at the formulation and implementation stages (SCHREYÖGG; STEINMANN, 1987; GOVINDARAJAN, 1988; 
SIMONS, 1990, KAPLAN; NORTON, 2001). However some authors assert that MCS are only useful for strategy evaluation (GOOLD; QUINN, 1990; PREBLE, 1992, GITTELL, 2000).

The last major and popular contributions came from the same school in the US. Kaplan and Norton $(1992,1993,1996)$ introduced the balanced scorecard, and Simons (1994, 2000) presented his model of levers of control. The balanced scorecard can be used to support and enable innovation, operations, and post-sale service processes (KAPLAN; NORTON, 1992, 1993, 1996; EPSTEIN; MANZONI, 1997). The model of levers of control proposed that business strategy's control is achieved by integrating the four systems of beliefs, boundary, diagnostic and interactive control (SIMONS, 2000), because they would inspire commitment to the organization's purpose, stake out the territory for experimentation and competition, coordinate and monitor the execution of today's strategies, and stimulate and guide the search for strategies of the future. Although this two tools represent an important contribution, among academicians they are not well accepted (LIPE; SALTERIO, 2000, 2002; BANKER; CHANG; PIZZINI, 2004).

\section{CRITICS OF MCS VIEWED AS PERMANENT STRUCTURES}

Over the period from 1960s to the mid 1980s there was a very clear split between management accounting research concentrated on the practice of management accounting and the research published in the higher-status US academic journals. To Argenti (1976) it appeared that the 1970s were the era of simple techniques and that complex alternatives were unlikely to be implemented. Coates, Smith and Stacey (1983) concludes that there appears to be a substantial gap between theory and practice. In another study Gregory and Piper (1983) found little evidence of use of sophisticated techniques for stock control. This arid mathematic and economic modeling broke down in the mid-1980s when it became clear that the world of practice was completely uninterested, and the refinement of techniques had reached a stage of rarification where a small number of researchers were, in effect, talking only to themselves (PUXTY 1993).

A second significant shortcoming of MCS research is the fact that control systems designed to satisfy external reporting requirements do not facilitate process control within cost centers and leads to inaccurate and distorted individual product costs. Some researchers began to study management accounting in practice in order to gain better understanding of its role within the organization (SCAPENS, 1985). All that was required was to return to basics, to ask what makes sense and what is important for the organization. Rather than attempt to extract such information from a system designed primarily to satisfy external reporting and auditing requirements, it has been argued that systems' design shall be consistent with organization's technology, its product strategy and structure (JOHNSON; KAPLAN, 1987).

These two inconsistencies, the gap between theory and practice and managerial accounting based on external reporting systems, have been addressed from four angles. These four angles are identified as critiques and are related with human relations, managerialism, goal congruence, and relevance lost (MACINTOSH, 1994). A more radicalized human relations critique emerged in the 1980's and although it is not considered a new critique, for the purpose of this study it is listed separately. In the following paragraphs each of these critiques are briefly introduced.

The human relations critique focuses directly on the effects of people working in organizations. Many insights emerged, particularly a growing understanding of the social dynamics of budgeting, and the way different styles of using accounting information by superiors affects subordinates (MACINTOSH, 1994). This critique allowed the accounting community to start working on behavioral approaches to managerial accounting in the mid 60 's to complement or dispute the conclusions of studies aligned with the conventional 
wisdom, mathematical modeling, systems approach and Anthony's framework.

The managerialism critique can be thought of as a package of ideas, beliefs, and values based on the premise that managers and managerial functions are essential ingredients of contemporary organizations. Simon (1957), following the line of reasoning of Barnard (1938), declared that managerial decision-making is the very heart of organization and administration, but managers have to be conceived as individuals that take decisions. This critique gave rise to the HIP approach in the late 60's where emphasis is on the decisionmaking process of individual managers.

The goal congruence critique is associated with the followers of the MCS schools such as Dean, Anthony and Dearden. Responsibility center managers almost routinely make some decisions contrary to the overall interest of the organization, but it makes themselves look good under the prevailing scorekeeping method (MACINTOSH, 1994). Agency theory devotes a lot of effort to design optimal contracts, although this critique help to realize that the same bottom line cannot be used for all purposes, giving rise to contingent approaches and further refinements of transaction costs economics and agency theory.

The relevance lost movement started in 1982 with a paper presented by Robert Kaplan, that stated that the problem with the US manufacturing performance could be traced to management accounting techniques and practices that did not matched manufacturing environment. The proponents of relevance lost offer strategic cost management as a solution (MACINTOSH, 1994). This critique has originated the latest strategic approach that is being widely used by practitioners and cautiously analyzed by academicians.

In the mid 1980's the human relations critique evolved into a somewhat new concept that asserted that studies of the organizational roles of accounting should be complemented by studies of the societal roles of accounting (MILLER, 2007). A view that the environment was not exogenous to accounting structures and processes, but instead it 'passes through them' lead researchers to look beyond the organization and to see changes within the organizations as dynamically linked with changes in the wider environment. Studies of power, influence and control complemented studies of the behavioral aspects of accounting within organizations. This critique is more aligned with a shift of behavioral studies from a functionalist paradigm to an interpretivist paradigm, because MCS do not have a real ontological existence, instead MCS meaning is given by the subjects or institutions at play.

\section{EVOLUTION MAP OF MANAGEMENT CONTROL SYSTEMS LITERATURE: FUNCTIONALIST PARADIGM}

The evolution of approaches during the twentieth century is explained in Figure 2. For simplicity in the presentation, the map of Figure 2 does not consider the external contributions to the field, such as microeconomics and psychology. MCS started with a conventional accumulated wisdom that latter evolved into a more precise mathematical modeling. These approaches considered organizations as closed units until systems theory opened the research to include the impact of the environment. Within open systems perspective, Robert Anthony developed a model of three interconnected subsystems. All these approaches were highly concentrated in the organization leaving aside human elements; thanks to the human relations critique the behavioral approach entered in the field of MCS. The modeling of impersonal decision rules lead to the appearance of the managerial critique and consequently the human information processing approach. The separation between managers and owners originated conflicts that were addressed by the goal congruence critique that based on the known rationality of transaction costs improved the tools and models developed by agency theory.

Each approach partially explains the phenomena of MCS, so in an attempt to merge all of them, contingency theory introduces cause-effect models based on multiple factors. The last widely accepted approach is strategic accounting proposed by the lost relevance critique, 
although some of it work and authors have been labeled as 'not scientific' because it focuses on developing useful 'ready to use tools' without referring to an underlying theory. Although the scope of this study is to summarize the evolution of MCS literature within the functionalist paradigm, it is worth to notice how the behavioral approach was influenced by the radicalized version of the human relations critique, accounting as a social practice. This critique gave rise to four approaches that encompass most of the studies done in the interpretivist paradigm.

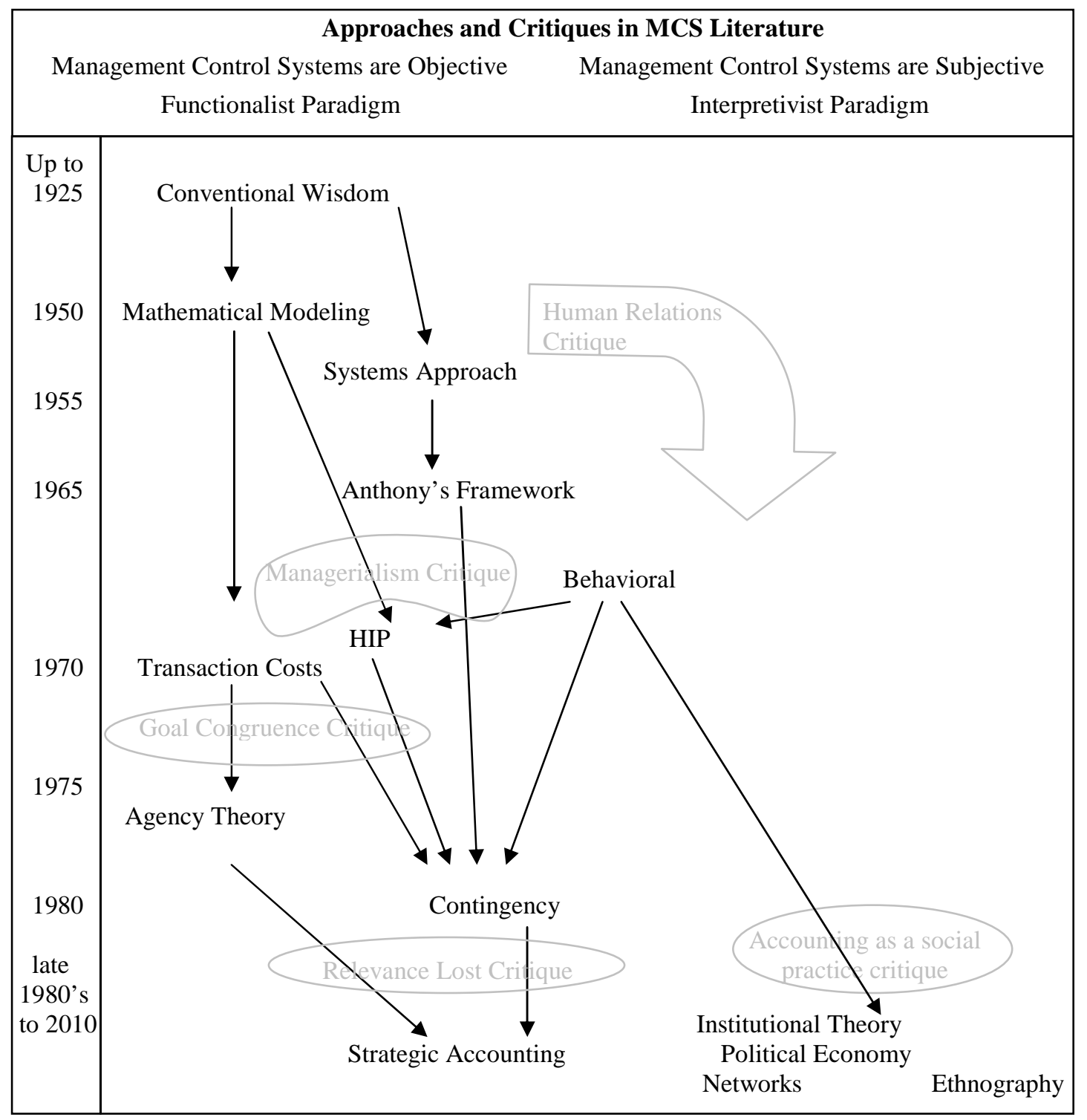

Figure 2 - Map of the evolution of approaches and critiques in MCS literature

Obs.: not considering external contributions to the field, such as microeconomics and psychology

\section{CONCLUSION}

This paper summarized the evolution of MCS literature within the functionalist paradigm. The functionalist paradigm was selected because it has the largest number of academic studies published and it is the oldest in the discipline of management accounting. This study followed the historical evolution, putting special emphasis in organizing the disperse body of research. The historical analysis, framed as a timeline, allowed focusing on the diverse research that has dominated the field since the beginning of 1900s and to organize them in clusters around a certain theory or framework. 
The transition from one cluster of theory or framework to another was explained by the existence of critiques; however, some theories and frameworks evolved naturally into others without the need of a critique. The purpose of this paper was to draw a map of the evolution and current state of the theories behind management accounting within the functionalist paradigm (PUXTY, 1993) as an aid for researchers and advanced business students.

The contradictions are clearer now, but have not been solved. The contributions to MCS evolution and understanding have been impressive, but seems that real needs of companies are not well assessed by academicians, labeling as 'not scientific' those researchers and consultants that focus on developing useful 'ready to use tools'. In summary, MCS practice and literature has evolved for more than 100 years adapting to the environment, however there is still a long way to go to be more focused on solving companies needs within the framework of robust theories.

\section{REFERENCES}

ANDERSON, S.; GLENN, D.; SEDATOLE, K. Sourcing parts of complex products: evidence on transactions costs, high-powered incentives and ex-post opportunities. Accounting, Organizations and Society, v. 25, n. 8, p. 723-749, 2000. doi:10.1016/S03613682(00)00015-5

ANTHONY, R. The management control function. Boston, MA: Harvard Business School Press, 1965.

ANTHONY, R.; GOVINDARAJAN, V. Management control systems. 12 ed. McGraw Hill, 2007.

ANTLE, R.; DEMSKI, J. The controllability principle in responsibility accounting. The Accounting Review, v. 63, n. 4, p. 700-718, 1988.

ARGENTI, J. Whatever happened to management techniques? Management Today, p. 178179, April, 1976.

ARGYRIS, C. The impact of budgets on people. The Controllership Foundation. Ithaca, 1952.

ARROW, K. The limits of organization. New York: Norton, 1974.

ATKINSON, A. Financial and management accounting: the odd couple. CMA Magazine, p. 42-46, Dec./Jan., 1989.

BAIMAN, S. Agency research in managerial accounting: a second look. Accounting Organizations and Society, v. 15, n. 4, p. 341-371, 1990. doi:10.1016/0361-3682(90)90023$\mathrm{N}$

BANKER, R.; CHANG, H.; PIZZINI, M. The Balanced Scorecard: judgmental effects of performance measures linked to strategy. The Accounting Review, v. 79, n. 1, p. 1-23, 2004. doi:10.2308/accr.2004.79.1.1

BANKER, R; HUGES, J.S. Product costing and pricing. The Accounting Review, n. 69, p. 479-494, 1994. doi: 10.2308/jmar.2002.14.1.79

BANKER, R.; DATAR, S. M., KEKRE, S. Relevant costs, congestion and stochasticity in production environments. Journal of Accounting and Economics, n. 10, p. 171-197, 1988. doi:10.1016/0165-4101(88)90002-X

BARNARD, C. The functions of the executive. Cambridge, Mass: Harvard University Press, 1938. 
BELKAOUI, A. Handbook of cost accounting theory and techniques. New York: Quorum Books, 1991.

BELLO, D.; LOHTIA, R.; DANT, S. Collaborative relationships for component development: the role of strategic issues, production costs, and transaction costs. Journal of Business Research, v. 45, n. 1, p. 15-31, 1999. doi:10.1016/S0148-2963(98)00006-X

BIRNBERG, J. G.; TUROPOLEC, L.; YOUNG, S. M. The organizational context of accounting. Accounting, Organizations and Society, 111-129, 1983. doi:10.1016/03613682(83)90018-1

BORITZ, J. Management accounting: a discipline in transition. CA Magazine, p. 75-85, Jan./Feb., 1988.

BOUGEN, P.; OGDEN, S.; OUTRAM, Q. The appearance and disappearance of accounting: wage determination in the UK coal industry. Accounting, Organizations and Society, v. 15, n. 3, p. 149-170, 1990. doi:10.1016/0361-3682(90)90001-B

BOULDING, K. E. General systems theory-the skeleton of science. Management Science, p. 197-208, 1956. doi:10.1287/mnsc.2.3.197

BUCKLEY, J. Comments on 'the organizational context of accounting'. Accounting, Organizations and Society, p. 131-135, 1983. doi:10.1016/0361-3682(83)90019-3

BURNS, T.; STALKER, G. M. The management of innovation. London: Tavistock, 1961.

BURNS, W. J.; WATERHOUSE, J. H. Budgetary control and organization structure. Journal of Accounting Research, p. 177-203, 1975. doi:10.2307/2490360

CHANDLER, A. Strategy and structure. Cambridge, Mass: MIT Press, 1962.

CHANDLER, A. The visible hand: the managerial revolution in American business. Cambridge, Mass: Harvard University Press, 1977.

CHAPMAN, C.; HOPWOOD, A.; SHIELDS, M. Handbook of management accounting research. Amsterdam, NLD: Elsevier Science and Technology Books, 2007. Vol. 1.

CHAPMAN, C. Reflections on a contingent view of accounting. Accounting, Organizations and Society, v. 22, n. 2, p. 189-205, 1997. doi:10.1016/S0361-3682(97)00001-9

CHENHALL, R. Theorizng contingencies in management control systems research. In:HOPWOOD, A.; CHAPMAN, C.; SHIELDS, M. (Orgs.). Handbook of management accounting research. Amstrerdam, NLD: Elsevier Science and Technology Books, 2007. Vol. 1. pp 163-205. doi: 10.1016/S1751-3243(06)01006-6

CHRISTENSEN, J. Communication in agencies. The Bell Journal of Economics, p. 661674, 1981. doi:10.2307/3003580

CHUA, W. Experts, networks and inscriptions in the fabrications of accounting image: a story of the representation of three public hospitals. Accounting, Organizations and Society, v. 20, n. 2, p. 111-145, 1995. doi:10.1016/0361-3682(95)95744-H

$\mathrm{CHURCH}, \mathrm{A}$. The science and practice of management. Engineering Magazine Company, New York, 1914. Originally serialized in six parts as "Practical Principles of Rational Management”. Engineering Magazine, p. 44-45, Jan./Jul., 1913.

COATES, J.; SMITH, J.; STACEY, R. Results of a preliminary survey into the structure of divisionalized companies, divisionalised performance appraisal and the associated role of management accounting. In: COPPER, D.; SCAPENS, R.; ARNOLD, J. (Org.). Management accounting research and practice. Institute of Cost and Management 
Accountants, 1983.

COOPER, C.; PUXTY, A. On the proliferation of accounting (his)tories. Critical Perspectives on Accounting, v. 7, p. 285-313, 1996. doi:10.1006/cpac.1996.0034

COVALESKI, M.; DIRSMITH, M. The use of budgetary symbols in the political arena: an historically informed field study. Accounting, Organizations and Society, v. 20, n. 2/3, p. 124, 1988. doi:10.1016/0361-3682(88)90023-2

COVALESKY, M.; DIRSMITH, M. Dialectic tension, double reflexivity and the everyday accounting researcher: on using qualitative methods. Accounting, Organizations and Society, v. 15, p. 543-573, 1990. doi:10.1016/0361-3682(90)90034-R

DE ROOVER, R. A florentine firm of cloth manufactures. In: DE ROOVER (Org.). Business, banking, and economic thought in late medieval and early modern Europe. Chicago: The University of Chicago Press, 1974.

DEKKER, H. Control of inter-organizational relationships: evidence on appropriation concerns and coordination requirements. Accounting, Organizations and Society, v. 29, n.1, p. 27-50, 2004. doi:10.1016/S0361-3682(02)00056-9

DEMSKI, J. Information improvement bounds. Journal of Accounting Research, p. 58-76, 1972a. doi:10.2307/2490218

DEMSKI, J. Optimal performance measurement. Journal of Accounting Research, v. 10, n. 2, p. 243-258, 1972b. doi:10.2307/2490007

DEMSKI, J. Information analysis. Reading, MA: Addison-Wesley, 1980.

DEMSKI, J. Managerial uses of accounting information. Norwell, MA: Kluwer Academic Publishers, 1994.

DEMSKI, J.; FELThAM, G. A. Forecast evaluation. The Accounting Review, p 533-548, July, 1972.

DEMSKI, J.; FELTHAM, G. A. Cost determination: a conceptual approach. Iowa State University Press, 1976.

DENT, J. F. Strategy, organization and control: some possibilities for accounting research. Accounting, Organizations and Society, n. 15, p. 3-25, Jan., 1990. doi: 10.1016/03613682(90)90010-R

DENT, J. F.; EZZAMEL, M. Organizational control and management accounting. In: EZZAMEL, M; HART, $H$. Advanced management accounting, an organizational emphasis. London, UK: Cassell Educational Limited, 1987. pp 86-112.

EGGLETON, I. Patterns, prototypes, and predictions: an exploratory study. Journal of Accounting Research, Supplement, p 68-131, 1986. doi: 10.2307/2490447

EISENHARDT, K. Control: organizational and economic approaches. Management Science, v. 31, n. 2, p. 134-149, 1985. doi:10.1287/mnsc.31.2.134

EMERSON, H. The twelve principles of efficiency. New York: Engineering Magazine Company. Originally serialized in sixteen parts. Engineering Magazine, v. 39-41, June 1910 through September 1911, 1912.

EMMANUEL, C.; OTLEY, D.; MERCHANT, K. Accounting for management control. 2. ed. London, UK: Chapman \& Hall, 1990.

EPSTEIN, M. J.; MANZONI, J. F. The Balanced Scorecard and Tableau du Bord: translating 
strategy into action. Management Accounting, v. 79, n. 2, p. 28-36, 1997.

EZZAMEL, M. Decision theory and information economics. In: EZZAMEL, M; HART, H. Advanced management accounting, an organizational emphasis. London, UK: Cassell Educational Limited, 1987. pp. 139-159.

EZZAMEL, M; HART. H. Advanced management accounting, an organizational emphasis. London, UK: Cassell Educational Limited, 1987.

FAYOL, H. General and industrial management. London; Pitman (Translated by Constance Storrs, originally published in French in 1916), 1949.

FERRARA, W.; HAYYA, J; NACHMAN, D. Normalcy of profit in the Jaedicke-Robichek Model. The Accounting Review, p. 299-307, Apr., 1972.

FERRARA, W. The 21st century paradigm. Management Accounting, p. 30-36, Dec., 1995.

FISCHER J. Contingency-based research on management control systems: categorization by level of complexity. Journal of Accounting Literature, n. 14, p. 24-53, 1995.

FISCHER, J.; GOVINDARAJAN, V. Incentive compensation design, strategic business unit mission, and competitive strategy. Journal of Management Accounting Research, n. 5, p. 129-144, 1993.

FLAMHOLTZ, D. The markets and hierarchies framework: a critique of the model's applicability to accounting and economic development. Accounting, Organizations and Society, v. 8, n. 2/3, p. 147-151, 1983. doi:10.1016/0361-3682(83)90022-3

FLAMHOLTZ, E. G.; DAS, T. K.; TSUI, A. S. Toward an integrative framework of organizational control. Accounting, Organizations and Society, v. 10, n. 1, p. 35-50, 1985. doi:10.1016/0361-3682(85)90030-3

FLAMHOLTZ, E. Accounting, budgeting and control systems. Accounting, Organizations and Society, v. 8, n. 2/3, p. 153-169, 1983. doi:10.1016/0361-3682(83)90023-5

FLIGSTEIN, N. The transformation of corporate control. Cambridge, MA: Harvard University Press, 1990.

FOLLET, M. Management as a profession. In: METCALF, H. (org.). Business management as a profession. Chicago: A Shaw Company, 1927.

FOSTER, G.; GUPTA, M. Manufacturing overhead cost driver analysis. Journal of Accounting and Economics, n. 12, p. 309-337, 1990. doi:10.1016/0165-4101(90)90052-6

FOUCAUlT, M. Power/Knowledge. Harvester: Colin Gordon, 1980.

FROUD, J.; WILLIAMS, K.; HASLAM, C.; JOHAL, S.; WILLIAMS, J. Caterpillar: two stories and an argument. Accounting, Organizations and Society, v. 23, n. 7, p. 685-708, 1998. doi:10.1016/S0361-3682(97)00023-8

GALBRAITH, J. Designing complex organizations. Organization Development Series. Addison-Wesley, Reading, Mass, 1973.

GIDDENS, A. New rules of sociological method. Hutchinson, 1976.

GIGLIONI, G. B.; BEDEIAN, A. G. A conspectus of management control theory: 1900-1972. Academy of Management Journal, n. 17, p. 292-305, Jun., 1974.

GITTELL, J. Paradox of coordination and control. California Management Review, v. 42, n. 3, p. 101-117, 2000.

GIVENS, H. An application of curvilinear breakeven analysis. The Accounting Review, p. 
141-143, Jan., 1966.

GOGGANS, T. Breakeven analysis with curvilinear functions. The Accounting Review, p. 867-871, Oct., 1965.

GOOLD, M.; QUINN, J. The paradox of strategic controls. Strategic Management Journal, n. 11, p. 43-57, 1990. doi:10.1002/smj.4250110104

GORDON, L. A.; MILLER, D. A contingency framework for the design of accounting information systems. Accounting, Organizations and Society, p. 59-69, 1976. doi:10.1016/0361-3682(76)90007-6

GOVINDARAJAN, V. A Contingency approach to strategy implementation at the businessunit level: integrating administrative mechanisms with strategy. Academy of Management Journal, v. 31, n. 4, p. 828-853, 1988. doi:10.2307/256341

GOVINDARAJAN, V.; FISCHER, J. Strategy, control systems and resource sharing: effects on business-unit performance. Academy of Management Journal, v. 33, n. 2, p. 259-285, 1990. doi: $10.2307 / 256325$

GOVINDARAJAN, V.; GUPTA, A. K. Linking control systems to business strategy, impact on performance. Accounting, Organizations and Society, v. 10, n. 1, p. 51-66, 1985. doi:10.1016/0361-3682(85)90031-5

GRANOVETTER, M. Economic action and social structure: the problem of embeddeness. American Journal of Sciology, n. 91, p. 481-510, 1985. doi: 10.1086/228311

GREGORY, G.; PIPER, J. A study of the raw material reorder decisions in small batch manufacturing companies. In: COOPER, D.; SCAPENS, R.; ARNOLD, J. (eds.). Management Accounting Research and Practice, Institute of Cost and Management Accountants, 1983.

GROOT, T.; MERCHANT, K. Control of international joint ventures. Accounting, Organizations and Society, n. 25, p. 579-607, 2000. doi:10.1016/S0361-3682(99)00057-4

HABERMAS, J. The theory of communicative action. Polity. 1984. Vol 1.

HABERMAS, J. The theory of communicative action. Polity. 1987. Vol 2.

HAMBRICK, D. Environment, strategy and power within top management teams. Administrative Science Quarterly, n. 5, p. 253-276, 1981.

HAYES, D. The contingency theory of managerial accounting. The Accounting Review, v. 52, n. 1, p. 22- 39, 1977.

HIRST, M. Accounting information and the evaluation of subordinate performance: a situational approach. The Accounting Review, p. 771-784, 1981.

HOFSTEDE, G. The game of budget control. London: Tavistok, 1968.

HOFSTEDE, G. Management control of public and non-for-profit activities. Accounting, Organizations and Society, v. 6, n. 3, p. 193-211, 1981. doi:10.1016/0361-3682(81)90026-X HOGARTH, R. Judgement and choice. New York: Wiley, 1980.

HOLDEN, P; FISK, L; SMITH, H. Top management organization and control. California: Stanford University Press, 1941.

HOLMSTROM, B. Moral hazard and observability. The Bell Journal of Economics, p. 7491, 1979. doi: $10.2307 / 3003320$

HOPPER, T; MACINTOSH, N. Management accounting as disciplinary practice. 
Management Accounting Research, p. 181-216, 1993. doi:10.1006/mare.1993.1011

HOPWOOD, A. An empirical study of the role of accounting data in performance evaluation. Journal of Accounting Research, Supplement, p. 156-193, 1972. doi:10.2307/2489870

HOPWOOD, A. The archaeology of accounting systems. Accounting Organizations and Society, n. 12, p. 207-234, 1987. doi:10.1016/0361-3682(87)90038-9

HORNGREN, C. Management accounting: Where are we? Management accounting and control. Madison: University of Wisconsin, 1975.

JAEDICKE, R. K.; ROBICHECK, A. Cost-volume-profit analysis under conditions of uncertainty. The Accounting Review, p. 917-926, Oct., 1964.

JENSEN, M. C.; MECKLING, W. H. Theory of the firm: managerial behavior, agency costs, and ownership structure. Journal of Financial Economics, p. 305-360, Oct., 1976. doi:10.1016/0304-405X(76)90026-X

JOHNSON, H. Toward a new understanding of nineteenth century cost accounting. The Accounting Review, p. 510-551, Jul., 1981.

JOHNSON, H. The search for gain in markets and firms: a review of the historical emergence of management accounting systems. Accounting. Organizations and Society, v. 8, n. 2/3, p. 139-146, 1983. doi:10.1016/0361-3682(83)90021-1

JOHNSON, H. Relevance regained: from top-down control to bottom-up improvement. New York: The Free Press, 1992.

JOHNSON, T.; KAPLAN, R. Relevance lost: the rise and fall of management accounting. Boston, Ma: Harvard Business School Press, 1987.

KAPLAN, R. Advanced management accounting. Englewood Cliffs, NJ: Prentice Hall, Inc., 1982.

KAPLAN, R. The evolution of management accounting. The Accounting Review, v. 59, n. 3, p. 390-418, 1984.

KAPLAN, R.; NORTON, D. Transforming the balanced scorecard from performance measurement, to strategic management. Part I. Accounting Horizons, v. 15, n. 1, p. 87-105, 2001. doi:10.2308/acch.2001.15.1.87

KAPLAN, R.; NORTON, D. The Balanced Scorecard: measures that drive performance. Harvard Business Review, p. 71-79, Jan./Feb., 1992.

KAPLAN, R.; NORTON, D. Putting the Balanced Scorecard to work. Harvard Business Review, p. 134-142, Sep./Oct., 1993.

KAPLAN, R.; NORTON, D. Using the Balanced Scorecard as a strategic management system. Harvard Business Review, 75-85, Jan./Feb., 1996.

KAPLAN, R.; COOPER, R. Cost \& effect. Boston: Harvard Business Press, 1997.

KUHN, T. The structure of scientific revolution. 2. ed. Chicago: University of Chicago Press, 1970.

LANGFIELD-SMITH, K. Management control systems and strategy: a critical review. Accounting, Organizations and Society, v. 22, n. 2, p. 207-232, 1997. doi:10.1016/S03613682(95)00040-2

LAWRENCE, P. R.; LORSCH, J. W. Organization and environment: managing differentiation and integration. Boston: Harvard Business School Press, 1967, reprint 1986. 
LAWSON, F. Industrial control. London: Pitman, 1920.

LEE, J. Managerial accounting changes for the 1990s. New York: Addison-Wesley Publishing Co., 1987.

LIAO, M. Model sampling: a stochastic cost-volume-profit analysis. The Accounting Review, p. 780-790, Oct., 1975.

LIPE, M.; SALTERIO, S. The Balanced Scorecard: judgmental effects of common and unique performance measures. The Accounting Review, v. 75, n. 3, p. 283-298, 2000. doi:10.2308/accr.2000.75.3.283

LIPE, M.; SALTERIO, S. A Note on the judgmental effects of the Balanced Scorecard's information organization. Accounting Organizations and Society, n. 27, p. 531-540, 2002. doi:10.1016/S0361-3682(01)00059-9

LUFT, J. Long-term change in management accounting: perspectives from historical research. Journal of Management Accounting Research, n. 9, p. 161-195, 1997.

MACINTOSH, N. Management accounting and control systems: an organizational and behavioral approach. New York: Wiley, 1994.

MACINTOSH, N.; DAFT, R. L. Management control systems and departmental interdependencies: an empirical study. Accounting, Organizations and Society, p. 40-61, 1987. doi: 10.1016/0361-3682(87)90015-8

MACINTOSH, N.; SCAPENS, R. W. Structuration theory in management accounting. Accounting, Organizations and Society, p. 455-477, 1990. doi:10.1016/03613682(90)90028-S

MACINTOSH, N.; SCAPENS, R. W. Management accounting and control systems: a structuration theory analysis. Journal of Management Accounting Research, p. 131-158, 1991.

MARSCHAK, T; RADNER, R. Economic theory of teams. New Haven, CT: Yale University Press. 1972.

MERCHANT, K.; SIMONS, R. Research and control in complex organizations: an overview. Journal of Accounting Literature, n. 5, p. 183-200, 1986.

MERCHANT, K.; VAN DER STEDE, W. Management control systems: text and cases. 2. ed. New York: Prentice Hall, 2007.

MEYER, J.; ROWAN, B. Institutionalized organizations: formal structure as myth and ceremony. American Journal of Sociology, v. 83, n. 2, p. 340-363, 1977. doi: $10.1086 / 226550$

MILLER, P. Management accounting and sociology. In: HOPWOOD, A.; CHAPMAN, C.; SHIELDS, M. (eds.). Handbook of management accounting research. Amstrerdam, NLD: Elsevier Science and Technology Books, 2007. pp 285-295. Vol. 1. doi: 10.1016/S17513243(06)01010-8

MILLER, L; BUCKMAN, A. G. Cost allocation and opportunity costs. Management Science, v. 33, n. 5, p. 626-639, 1987. doi:10.1287/mnsc.33.5.626

MORRISON, T. A.; KACZKA, E. A new application of calculus and risk analysis to costvolume-profit changes. The Accounting Review, p. 330-343, Apr., 1969.

NANDAKUMAR, P; DATAR, S; AKELLA, R. Models for measuring and accounting for cost of conformance quality. Management Science, v. 39, n. 1, p. 1-16, 1993. 
doi:10.1287/mnsc.39.1.1

NIKIAS, A.; SCHWARTZ, S.; SPIRES, E.; WOLLSCHEID, J.; YOUNG, R. The effects of aggregation and timing on budgeting: an experiment. Behavioral Research in Accounting, v. 22 , n. 1, p. 67-83, 2010. doi:10.2308/bria.2010.22.1.67

OTLEY, D. Budget use and managerial performance. Journal of Accounting Research, p. 122-149, 1978. doi: $10.2307 / 2490414$

OTLEY, D. The Contingency theory of management accounting: achievement and prognosis. Accounting, Organizations and Society, p. 413-428, 1980. doi:10.1016/03613682(80)90040-9

OTLEY, D. Concepts of control: the contribution of cybernetic and systems theory to management control. In: LOWE, E.; MACHIN, J. (eds.). New perspectives in management control. London: Macmillan, 1983.

OTLEY, D. Management control in contemporary organizations: towards a wider framework. Management Accounting Research, n. 5, 289-299, 1994. doi: 10.1006/mare.1994.1018

OTLEY, D.; BROADBENT, J.; BERRY, A. Research in management control: an overview of its development. British Journal of Management, v. 6, Special Issue, p. 31-44, 1995. doi:10.1111/j.1467-8551.1995.tb00136.x

OUCHI, W. The relationship between organizational structure and organizational control. Administrative Science Quarterly, p. 95-113, Mar., 1977. doi:10.2307/2391748

OUCHI, W. A conceptual framework for the design of organizational control mechanisms. Management Science, n. 25, p. 833-848, Sep., 1979. doi: 10.1287/mnsc.25.9.833

OUCHI, W. Markets, bureaucracies and clans. Administrative Science Quarterly, v. 25, n. 1, p. $129-138$, 1980. doi:10.2307/2392231

PERROW, C. Organizational analysis: a sociological view. Belmont, Ca: Wadsworth, 1970.

PORPORATO, M.; SANDIN, A.; SHAW, L. An analysis of trends in doctoral dissertations in accounting 1991-2000. Advances in Accounting, n. 20, p. 245-263, 2003. doi:10.1016/S0882-6110(03)20011-0

PORTER, M. Competitive advantage. New York, Free Press, 1985.

POWELL, P. Human information processing. In: EZZAMEL, M; HART, H. Advanced management accounting: an organizational emphasis. London, UK: Cassell Educational Limited, 1987. pp 113-136.

PREBLE, J. F. Towards a comprehensive system of strategic control. Journal of Management Studies, v. 29, n. 4, p. 391-409, 1992. doi:10.1111/j.1467-6486.1992.tb00671.x

PRESTON, A.; COOPER, D.; COOMBS, R. Fabricating budgets: a study of the production of management budgeting in National Health Service. Accounting, Organizations and Society, v. 17, n. 6, p. 561-593, 1992. doi:10.1016/0361-3682(92)90014-J

PUXTY, A. The social \& organizational context of management accounting. The Advanced Management Accounting and Finance Series, The Chartered Institute of Management Accounts, Academic Press, 1993.

ROBSON, K. On the arenas of accounting change: the process of translation. Accounting, Organizations and Society, v. 16, n. 5, p. 547-570, 1991. doi:10.1016/0361-3682(91)90041$\mathrm{C}$ 
ROGERSON, W. Repeated moral Hazard. Econometrica, v. 53, n. 1, p. 69-76, 1985. doi:10.2307/1911724

RONEN, J; LIVINGSTONE, J. L. Expectancy theory approach to the motivational impacts of budgets. The Accounting Review, p. 671-685, Oct., 1975.

ROSS, S. The economic theory of agency: the principal's problem. American Economic Review, n. 63, p. 134-139, 1973.

SCAPENS, R. Management accounting: organizational theory and capital budgeting - three surveys. London: Macmillan, 1985.

SCHREYÖGG, G; STEINMMANN, H. Strategic control: a new perspective. Academy of Management Review, v. 12, n. 1, p. 91-103, 1987. doi:10.2307/257996

SHANK, J.; GOVINDARAJAN, V. Strategic cost analysis: the evolution from managerial to strategic accounting. Irwin, 1989.

SIEGEL, G.; RAMANAUSKAS-MARCONI, H. Behavioral accounting. Cincinnati, Ohio: South-Western Publishing Co., 1989.

SIKKA, P.; WILLMOTT, H. The dark side of transfer prices: its role in tax avoidance and wealth retentiveness. Critical Perspectives on Accounting, n. 21,p. 342-356, 2010. doi:10.1016/j.cpa.2010.02.004

SIMON, H. Administrative behaviour. 2. ed. New York: MacMillan, 1957.

SIMONS, R. How new top managers use control systems as levers of strategic renewal. Strategic Management Journal, n. 15, p. 169-189, 1994. doi:10.1002/smj.4250150301

SIMONS, R. Accounting control systems and business strategy: an empirical analysis. Accounting, Organizations and Society, v. 12, n. 4, p. 357-374, 1987. doi:10.1016/03613682(87)90024-9

SIMONS, R. The role of management control systems in creating competitive advantage: new perspectives. Accounting, Organizations and Society, v. 15, n. 1/2, p. 127-143, 1990. doi:10.1016/0361-3682(90)90018-P

SIMONS, R. Performance measurement \& control systems for implementing strategy: text and cases. Upper Saddle River, NJ: Prentice Hall, 2000.

THOMPSON, J. Organizations in action. New York: MacGraw Hill Books, 1967.

TIESSEN, P.; WATERHOUSE, J. H. Towards a descriptive theory of management accounting. Accounting, Organizations and Society, v. 8, n. 2/3, p. 251-267, 1983. doi:10.1016/0361-3682(83)90033-8

TINKER, T.; MERINO, B.; NEIMARK, M. The normative origins of positive theories, ideology and accounting thought. Accounting, Organizations and Society, v. 7, n. 2, p. 167200, 1982. doi:10.1016/0361-3682(82)90019-8

URWICK, L. Principles of direction and control. In: LEE, J. (org.). Dictionary of industrial administration. London: Pitman, 1928. Vol 1.

WATERHOUSE, J. H; TIESSEN, P. A contingency framework for management accounting systems research. Accounting, Organizations and Society, p. 65-76, Aug., 1978. doi:10.1016/0361-3682(78)90007-7

WEBER, M. The theory of social and economic organization. New York: The Free Press, 1947. 
WILLIAMSON, O. Corporate control and business behavior. Englewood Cliffs, NJ: Prentice Hall, 1970.

WILLIAMSON, O. Markets and hierarchies: analysis and antitrust implications. New York: Free Press, 1975.

WILLIAMSON, O. The modern corporation: origins, evolution, attributes. Journal of Economic Literature, n. 19, p. 1537-1568, Dec., 1981.

WOODWARD, J. Industrial organization: theory and practice. London: Oxford University Press, 1965.

ZIMMERMAN, J. The cost and benefits of cost allocations. The Accounting Review, p. 504521, Jul., 1979.

ZIMMERMAN, J. Accounting for decision management and control. 2. ed. Chicago: Irwin, 1997. 